\title{
DAMPAK LIKUIDITAS, RISIKO KREDIT DAN DANA PIHAK KETIGA TERHADAP PROFITABILITAS PADA BANK PERKREDITAN RAKYAT TANGERANG
}

\author{
Ade Onny Siagian \\ Universitas Bina Sarana Informatika; Jakarta, Indonesia \\ Email: ade.aoy@bsi.ac.id
}

\begin{abstract}
The purpose of this study is to find the profitability of a financial ratio that measures industry expertise in using its assets to generate profits. Continuing to be large, profitability shows that the industry's performance continues to be good, because the rate of return continues to be large. There are several variables that affect the profitability of a bank, namely liquidity, credit risk and third party funds. A bank is an institution that acts as a financial intermediary between parties that have excess funds and those who lack funds. The performance of a bank can be assessed through the financial statements presented by Bank Indonesia by carrying out an analysis using financial ratios. This research was conducted on the financial statements of BPR Tangerang Regency for the period 2016-2019. This research has the theme "The Effect of Liquidity, Credit Risk and Third Party Funds on profitability at Rural Banks (BPR) in Tangerang Regency. To uncover the problems in this research, multiple linear regression analysis was used. Based on the test results simultaneously at the real level $(\alpha)=5 \%$ through the $F$ test it was found that the variables of liquidity, credit risk and third party funds have a significant effect on profitability at Rural Banks (BPR) in Tangerang Regency.
\end{abstract}

Keywords: Liquidity, profitability, credit risk and third party funds

\section{Pendahuluan}

Lembaga Keuangan ialah aktivitas yang meliputi menghimpun dana, maupun cuma menyalurkan dana tetapi dapat keduanya menghimpun dana serta menyalurkan dana (Kasmir, 2014: 12). lembaga keuangan ini dibedakan jadi 2 bagian ialah lembaga keuangan bank serta lembaga keuangan non- bank ( Triandaru dan Totol 2014: 5). Salah satu lembaga keuangan yang sangat berarti untuk perekonomian sesuatu negeri ialah Bank.

Berdasarkan penelitian sebelumnya yang telah dilakukan terhadap masing- masing variabel, penelitian mengenai pengaruh variabel likuiditas terhadap profitabilitas yang dilakukan oleh Ali Sulieman Alshatti (2015) dan By Rizwan Ali Khan \& Mutahhar Ali (2016) mendapatkan hasil bahwa variabel likuiditas berpengaruh negatif dan signifikan terhadap profitabilitas, namun ditemukan temuan lain oleh Sastrowinoto dan Suzuki (2017). memperoleh hasil berbeda dimana variabel likuiditas berpengaruh positif tidak signifikan terhadap profitabilitas. Penelitian lain Audhya (2018) juga memperoleh hasil 
penelitian yaitu bahwa likuiditas berpengaruh positif terhadap profitabilitas.

Permasalahan yang dikemukakan di atas belum disentuh dalam penelitian. Inilah fenomena ini yang mendorong peneliti untuk mengangkat BPR Tangerang sebagai lokasi penelitian, penelitian terdorong untuk mengetahui apakah ada pengaruh Likuiditas, Risiko kredit, dan Dana pihak ketiga terhadap fenomena profitabilitas yang terjadi pada BPR Tangerang didalam penelitian ini menggunakan dengan Return on Asset.

\section{Kerangka Teori}

Bank merupakan lembaga keuangan yang melalukan kegiatan ekonomi berupa menghimpun dana dari masyarakat dan kemudian menyalurkannya kembali kepada masyarakat. Bank juga dikenal sebagai tempat untuk menukar uang, memindahkan uang, atau menerima segala macam bentuk pembayaran dan setoran seperti pembayaran listrik, telepon, air, pajak, uang kuliah dan pembayaran lainnya. Aktivitas perbankan yang pertama adalah menghimpun dana dari masyarakat luas yang dikenal dengan istilah Funding (Irawan,2018).

Rasio yang menggambarkan kemampuan perusahaan memenuhi kewajiban (utang) jangka pendek yakni disebut dengan likuiditas (Fred Weston, 2017;129). Likuiditas dapat diukur menggunakan rasio Loan To Deposit Ratio (LDR) untuk mengukur likuiditas. Kemampuan bank dalam mengelola Loan to Deposit Ratio akan berpengaruh terhadap profitabilitas. Risiko likuiditas terjadi karena jumlah dana yang diperlukan untuk pembiayaan atau pemberian kredit semakin besar. Besarnya pembiayaan tersebut menunjukkan bahwa bank mengelola sebagian besar dananya dalam bentuk pembiayaan atau kredit sehingga pendapatan bunga dari hasil pembiayaan atau kredit tersebut juga meningkat. Semakin tinggi tingkat LDR pada suatu bank yakni sekitar 78100\% menandakan bahwa jumlah kredit yang disalurkan lebih maksimal maka profitabitabilitas yang dicapai juga maksimal begitu juga sebaliknya. Didukung dengan hasil penelitian yang dilakukan oleh Miadalyni (2018) dan Agustiningrum (2018) memperoleh hasil likuiditas berpengaruh positif dan signifikan terhadap profitabilitas. Temuan serupa juga diperoleh Fahrizal (2019) dimana diperoleh hasil bahwa likiditas berpengaruh positif dan signifikan terhadap ROA.

\section{Metode Penelitian}

Pendekatan yang digunakan dalam penelitian ini adalah pendekatan kuantitatif sedangkan metode penelitian yang digunakan adalah asosiatif. Penelitian ini dilakukan pada seluruh BPR Kabupaten Tangerang yang berjumlah 31 unit. BPR di Kabupaten Tangerang terdiri dari 29 Kecamatan, yaitu Kecamatan Balaraja, Cikupa, Cisauk, Cisoka, Curug, Gunung Kaler, Jambe, Jayanti, Kelapa Dua, Kemir, Kresek, Kronjo, Kosambi, Legok, Mauk, Mekarbaru, Pagedangan, Pakuhaji, Panongan, Pasar Kemis, Rajeg, Sepatan, Sepatan Timur, Sindang Jaya, Solear, Sukadiri, Sukamulya, Teluknaga dan Tigaraksa. Lokasi ini dipilih dikarenakan adanya peningkatan jumlah BPR di Kabupaten Tangerang dan diiringi dengan perubahan jumlah profitabiitas dan risiko yang terjadi di Kabupaten Tangerang.

Obyek dari penelitian ini adalah tingkat profitabilitas yang terdapat pada BPR di Kabupaten Tangerang periode 2016-2019. Penelitian ini menggunakan 4 variabel yang terdiri dari 1 variabel terikat dan 3 variabel bebas.Variabel yang digunakan adalah Profitabilitas (Y). Variabel bebas yang digunakan adalah Likuiditas $\left(\mathrm{X}_{1}\right)$, Risiko Kredit $\left(\mathrm{X}_{2}\right)$ dan Dana Pihak Ketiga $\left(\mathrm{X}_{3}\right)$.

Loan to Deposit Ratio (LDR) adalah rasio antara seluruh jumlah kredit yang diberikan bank dengan dana yang diterima oleh bank yang tercatat di www.bi.co.id di 
Kabupaten Tangerang periode 2016-2019. Satuan yang digunakan dalam rasio LDR adalah persentase dan formulanya dapat dirumuskan sebagai berikut:

$$
L D R=\text { Total Kredit Yang Disalurkan } \times 100 \%
$$

\section{Total DPK}

Tingkat risiko kredit diproksikan dengan Non Performing Loan (NPL), dikarenakan NPL dapat digunakan untuk mengukur sejauh mana kredit yang bermasalah dipenuhi dengan aktiva produktif yang dimiliki oleh suatu bank pada perusahaan sampel di Kabupaten Tangerang periode 2016-2019. Satuan yang digunakan dalam rasio Non Performing Loan (NPL) adalah persentase dan formulanya dapat dirumuskan sebagai berikut:

$\mathrm{NPL}=\frac{\text { Kredit bermaslah }}{\text { Total Kredit }} \times 100 \%$

Dana pihak ketiga di ukur menggunakan Ln pada pengolahan data sebab selisih data dana pihak ketiga antara setiap perusahaan perbankan terlalu besar, sehingga untuk menghindari distribusi data yang tidak normal digunakan Ln. Pengukuran DPK tahun 2016-2019 dapat dihitung dengan rumus sebagai berikut :

$$
\text { DPK }=\frac{\text { Dana Pihak Ketiga }}{\text { Total Kewajiban }} \times 100 \%
$$

Return On Asset (ROA)merupakan rasio perbandingan antara laba sebelum pajak dengan total asset perusahaan pada perusahaan sampel di Kabupaten Tangerang periode 2016-2019. Satuan yang digunakan dalam ROA adalah persentase dan formulanya dapat dirumuskan sebagai berikut.

$$
R O A=\frac{\text { Laba sebelum pajak }}{\text { Rata- rata total aset }} \times 100 \%
$$

Berdasarkan jenisnya, data yang digunakan dalam penelitian ini adalah data kuantitatif. Data kuantitatif dalam penelitian ini adalah angka-angka laporan keuangan tahunan BPR Tangerang dari tahun 2016-2019. Sumber data yang digunakan dalam penelitian ini adalah data sekunder.Data sekunder yang digunakan dalam penelitian ini yaitu laporan tahunan BPR Tangerang pada tahun 2016-2019. Data diperoleh dari media internet dengan website(www.bi.co.id).

Populasi dalam penelitian ini adalah seluruh BPR Tangerang pada tahun 20162019.Sampel yang digunakan merupakan sampel jenuh. Sampel ini menggunakan teknik sensus sehingga seluruh populasi penelitian digunakan sebagai sampel. Jadi Jumlah sampel dalam penelitian ini adalah 112 Sampel yang terdaftar di BI pada tahun 20162019.Metode pengumpulan data yang digunakan adalah observasi non-patisipan,mencari data langsung dari laporan keuangan pada BPR Tangerang. Selain itu, digunakan metode lain berupa pengumpulan data melalui studi pustaka dan Direktori Perbankan Indonesia dan melalui situs www.bi.go.id. Teknik analisi data yang digunakan berupa Analisis regresi berganda dan uji asumsi klasik. 


\section{Hasil dan Pembahasan}

Return On Asset (ROA) merupakan proksi untuk mengukur efektifitas perusahaan dalam menghasilkan laba. Besarnya profitabilitas pada BPR di Kabupaten Tangerang periode 2016-2019 dapat dilihat pada Tabel 2. berikut :

Tabel 1

ROA BPR di Kabupaten Tangerang periode 2016 - 2019

\begin{tabular}{|c|c|c|c|c|c|}
\hline \multirow{2}{*}{ No. } & \multirow{2}{*}{ Bank } & \multicolumn{3}{|c|}{ Tahun } & \multirow[b]{2}{*}{2019} \\
\hline & & 2016 & 2017 & 2018 & \\
\hline 1. & BPR Akasia Mas & $4 \%$ & $4 \%$ & $4 \%$ & $3 \%$ \\
\hline 2. & BPR Marcorindo Perdana & $5 \%$ & $5 \%$ & $6 \%$ & $6 \%$ \\
\hline 3. & BPR Pusaka Dana & $6 \%$ & $5 \%$ & $4 \%$ & $3 \%$ \\
\hline 4. & BPR Ragam Peran mandiri & $5 \%$ & $6 \%$ & $5 \%$ & $6 \%$ \\
\hline 5. & BPR Tunas Jaya Global & $5 \%$ & $4 \%$ & $5 \%$ & $4 \%$ \\
\hline 6. & BPR Aneka Danaraya & $6 \%$ & $6 \%$ & $5 \%$ & $4 \%$ \\
\hline 7. & BPR Gita Makmur Utama & $4 \%$ & $5 \%$ & $4 \%$ & $4 \%$ \\
\hline 8. & BPR Sisibahari Dana & $7 \%$ & $6 \%$ & $6 \%$ & $4 \%$ \\
\hline 9. & BPR Matahari Artadaya & $7 \%$ & $10 \%$ & $4 \%$ & $4 \%$ \\
\hline 10. & BPR Tritama Lumbung Cemerlang d/h Ra & $2 \%$ & $3 \%$ & $3 \%$ & $3 \%$ \\
\hline 11. & BPR Bintang EkoNo.mi Sejahtera & $5 \%$ & $5 \%$ & $4 \%$ & $4 \%$ \\
\hline 12. & BPR Makmur Merata & $8 \%$ & $8 \%$ & $8 \%$ & $8 \%$ \\
\hline 13. & BPR Rizky Barokah & $1 \%$ & $2 \%$ & $1 \%$ & $2 \%$ \\
\hline 14. & BPR Kuta Bumi Sidomukti & $5 \%$ & $3 \%$ & $2 \%$ & $1 \%$ \\
\hline & BPR Artha Makmur Lestari & $21 \%$ & $3 \%$ & $3 \%$ & $3 \%$ \\
\hline 16. & BPR Fidusia Civitas & $3 \%$ & $3 \%$ & $7 \%$ & $1 \%$ \\
\hline & BPR Nusantara Bona Pasogit 12 & $1 \%$ & $2 \%$ & $3 \%$ & $2 \%$ \\
\hline & BPR Arta Jakarta & $9 \%$ & $7 \%$ & $7 \%$ & $7 \%$ \\
\hline & BPR Vinski Mukti Arta & $6 \%$ & $6 \%$ & $6 \%$ & $5 \%$ \\
\hline & BPR Rifi Maligi & $4 \%$ & $4 \%$ & $4 \%$ & $4 \%$ \\
\hline & BPR Sehat Sejahtera & $5 \%$ & $4 \%$ & $4 \%$ & $2 \%$ \\
\hline & BPR Bumidhana Adigraha & $5 \%$ & $5 \%$ & $5 \%$ & $4 \%$ \\
\hline & BPR Artha Mitra Usaha & $5 \%$ & $6 \%$ & $4 \%$ & $4 \%$ \\
\hline & BPR Makmur Artha Sedaya & $1 \%$ & $2 \%$ & $3 \%$ & $3 \%$ \\
\hline & BPR Asri Cikupa Karya & $6 \%$ & $7 \%$ & $4 \%$ & $3 \%$ \\
\hline 26. & BPR Muara Sumber Dana & $6 \%$ & $3 \%$ & $3 \%$ & $1 \%$ \\
\hline & BPR Surya Prima Persada & $7 \%$ & $6 \%$ & $6 \%$ & $1 \%$ \\
\hline & BPR Kerta Raharjau & $6 \%$ & $6 \%$ & $7 \%$ & $5 \%$ \\
\hline & Nilai Maksimum & $21 \%$ & $10 \%$ & $8 \%$ & $8 \%$ \\
\hline & Nilai Minimum & $1 \%$ & $2 \%$ & $1 \%$ & $1 \%$ \\
\hline & Nilai Rata - Rata & $6 \%$ & $5 \%$ & $5 \%$ & $4 \%$ \\
\hline
\end{tabular}

Tabel 1 menunjukkan bahwa pada tahun 2016, profitabilitas paling tinggi terjadi pada BPR Artha makmur Lestari yaitu sebesar 21\% sedangkan profitabilitas yang paling rendah terjadi pada BPR Rizky Barokah, BPR Nusantara Bona Pasogit 12 dan BPR Makmur Artha Sedaya yaitu sebesar 1\%. Pada Tahun 2017 profitabilitas paling tinggi terjadi pada BPR Hari Depan yaitu sebesar $10 \%$ sedangkan profitabilitas yang paling rendah terjadi 
pada BPR Rizky Barokah, BPR Nusantara Bona Pasogit 12 dan BPR Makmur Artha Sedaya yaitu sebesar 2\%. Pada Tahun 2018 profitabilitas paling tinggi terjadi pada BPR Makmur Merata yaitu sebesar $8 \%$ sedangkan profitabilitas yang paling rendah terjadi pada BPR Rizky Barokah yaitu sebesar 1\%. Pada Tahun 2019 profitabilitas paling tinggi terjadi pada BPR Makmur Merata yaitu sebesar 8\% sedangkan profitabilitas yang paling rendah terjadi pada BPR Kuta Bumi Sidomukti, BPR Fidusia Civitas, BPR Muara Sumber Dana dan BPR Surya Prima Persada. Profitabilitas yang memiliki nilai tertinggi mengindikasikan bahwa BPR tersebut memiliki kemampuan yang baik dalam menggunakan aset yang dimiliki secara efektif, sehingga perusahaan memperoleh tingkat profitabilitas yang tinggi. Berbeda halnya dengan BPR yang memiliki nilai profitabilitas yang rendah mengindikasikan bahwa BPR tersebut gagal dalam memanfaatkan aset yang dimiliki untuk memperoleh profitabilitas yang tinggi. Rata-rata profitabilitas selama periode penelitian dari 2016-2019 mengalami fluktuasi setiap tahunnya yang secara ratarata mendekati 1 , oleh sebab itu dapat dikatakan sudah mencapai profitabilitas optimal

Risiko Likuiditas menggunakan proksi Loan to Deposit Ratio(LDR) pada BPR di kabupaten Tangerang. Besarnya Likuiditas pada BPR di Kabupaten Tangerang periode 2016-2019 dapat dilihat pada Tabel 3.

Tabel 2 menunjukkan bahwa pada tahun 2016, LDR paling tinggi pada BPR Pusaka Dana yaitu sebesar $98 \%$ sedangkan $L D R$ yang paling rendah terjadi pada BPR Fidusia Civitas yaitu sebesar 54\%. pada tahun 2017, LDR paling tinggi pada BPR Arta Jakarta yaitu sebeaar 97\% sedangkan LDR yang paling rendah terjadi pada BPR Makmur Artha Sedaya.

Tabel 2.

Tabel LDR BPR di Kabupaten Tangerang periode 2016 - 2019

\begin{tabular}{|c|c|c|c|c|c|}
\hline \multirow{2}{*}{ No } & \multirow{2}{*}{ Bank } & \multicolumn{3}{|c|}{ Tahun } & \multirow[b]{2}{*}{2019} \\
\hline & & 2016 & 2017 & 2018 & \\
\hline 1. & BPR Akasia Mas & $86 \%$ & $77 \%$ & $77 \%$ & $80 \%$ \\
\hline 2. & BPR Marcorindo Perdana & $95 \%$ & $92 \%$ & $86 \%$ & $93 \%$ \\
\hline 3. & BPR Pusaka Dana & $98 \%$ & $93 \%$ & $74 \%$ & $80 \%$ \\
\hline 4. & BPR Ragam Peran mandiri & $92 \%$ & $85 \%$ & $92 \%$ & $85 \%$ \\
\hline 5 . & BPR Tunas Jaya Global & $90 \%$ & $91 \%$ & $85 \%$ & $85 \%$ \\
\hline 6. & BPR Aneka Danaraya & $90 \%$ & $69 \%$ & $77 \%$ & $80 \%$ \\
\hline 7. & BPR Gita Makmur Utama & $88 \%$ & $86 \%$ & $81 \%$ & $84 \%$ \\
\hline 8. & BPR Sisibahari Dana & $93 \%$ & $82 \%$ & $83 \%$ & $21 \%$ \\
\hline 9. & BPR Matahari Artadaya & $89 \%$ & $95 \%$ & $87 \%$ & $84 \%$ \\
\hline 10. & BPR Tritama Lumbung Cemerlang d/h Ra & $84 \%$ & $90 \%$ & $89 \%$ & $80 \%$ \\
\hline 11. & BPR Bintang EkoNo.mi Sejahtera & $83 \%$ & $86 \%$ & $79 \%$ & $81 \%$ \\
\hline 12. & BPR Makmur Merata & $90 \%$ & $90 \%$ & $92 \%$ & $91 \%$ \\
\hline 13. & BPR Rizky Barokah & $84 \%$ & $85 \%$ & $84 \%$ & $79 \%$ \\
\hline 14. & BPR Kuta Bumi Sidomukti & $82 \%$ & $91 \%$ & $78 \%$ & $75 \%$ \\
\hline 15 . & BPR Artha Makmur Lestari & $88 \%$ & $87 \%$ & $84 \%$ & $86 \%$ \\
\hline 16. & BPR Fidusia Civitas & $54 \%$ & $73 \%$ & $69 \%$ & $68 \%$ \\
\hline 17. & BPR Nusantara Bona Pasogit 12 & $90 \%$ & $83 \%$ & $86 \%$ & $86 \%$ \\
\hline 18. & BPR Arta Jakarta & $92 \%$ & $97 \%$ & $89 \%$ & $95 \%$ \\
\hline 19. & BPR Vinski Mukti Arta & $84 \%$ & $94 \%$ & $87 \%$ & $81 \%$ \\
\hline
\end{tabular}


20. BPR Rifi Maligi

21. BPR Sehat Sejahtera

22. BPR Bumidhana Adigraha

23. BPR Artha Mitra Usaha

24. BPR Makmur Artha Sedaya

25. BPR Asri Cikupa Karya

26. BPR Muara Sumber Dana

27. BPR Surya Prima Persada

28. BPR Kerta Raharjau

\begin{tabular}{llll}
$88 \%$ & $87 \%$ & $94 \%$ & $88 \%$ \\
$89 \%$ & $88 \%$ & $86 \%$ & $83 \%$ \\
$77 \%$ & $76 \%$ & $72 \%$ & $67 \%$ \\
$83 \%$ & $74 \%$ & $67 \%$ & $66 \%$ \\
$73 \%$ & $68 \%$ & $78 \%$ & $73 \%$ \\
$80 \%$ & $78 \%$ & $71 \%$ & $63 \%$ \\
$81 \%$ & $79 \%$ & $77 \%$ & $66 \%$ \\
$88 \%$ & $85 \%$ & $89 \%$ & $87 \%$ \\
$80 \%$ & $82 \%$ & $92 \%$ & $90 \%$ \\
$98 \%$ & $97 \%$ & $94 \%$ & $95 \%$ \\
$54 \%$ & $68 \%$ & $67 \%$ & $21 \%$ \\
$85 \%$ & $84 \%$ & $82 \%$ & $78 \%$ \\
\hline
\end{tabular}

Pada Tahun 2018, LDR paling tinggi pada BPR Rifi Maligi sedangkan LDR yang paling rendah terjadi pada BPR Werdhi Sedana. Pada Tahun 2016, LDR paling tinggi pada BPR Artha Mitra Usaha sedangkan LDR yang paling rendah terjadi pada BPR Sisibahari Dana. LDR yang paling tinggi mengindikasikan bahwa lembaga keuangan tersebut dalam kondisi likuid atau perusahaan yang tidak mampu memenuhi kewajibannya, berbeda dengan halnya dengan BPR memiliki nilai likuiditas yang rendah mengindikasikan bahwa BPR dalam kondisi likuid atau perusahaan mampu memenuhi kewajiban tersebut. Rata-rata likuiditas selama periode penelitian dari 2016-2019 mengalami fluktuasi setiap tahunnya yang secara rata-rata mendekati $78-100 \%$, oleh sebab itu dapat dikatakan sudah mencapai likuiditas optimal

Data pada Tabel 3 menunjukkan bahwa pada tahun 2016, NPL paling tinggi pada BPR Muara Sumber Dana yaitu sebesar 12\% sedangkan NPL yang paling rendah terjadi pada BPR Surya Prima Persada, BPR Pusaka Dana, BPR Ragam Peran mandiri, dan BPR Tunas Jaya Global yaitu sebesar 0\%. Pada Tahun 2015, NPL paling tinggi pada BPR BPR Kuta Bumi Sidomukti dan BPR Muara Sumber Dana yaitu sebesar 6\% sedangkan NPL yang paling rendah terjadi pada BPR Surya Prima Persada, BPR Pusaka Dana, BPR Ragam Peran mandiri, dan BPR Tunas Jaya Global yaitu sebesar $0 \%$.

Tabel 3

NPL BPR di Kabupaten Tangerang periode 2016 - 2019

\begin{tabular}{r|r|cccc|}
\hline \multirow{2}{*}{ No } & \multicolumn{1}{|c|}{ Bank } & \multicolumn{4}{c|}{ Tahun } \\
\cline { 3 - 6 } & & 2016 & 2017 & 2018 & 2019 \\
\hline & & $2 \%$ & $3 \%$ & $2 \%$ & $4 \%$ \\
1. & BPR Akasia Mas & $1 \%$ & $1 \%$ & $1 \%$ & $3 \%$ \\
2. & BPR Marcorindo Perdana & $0 \%$ & $0 \%$ & $0 \%$ & $0 \%$ \\
3. & BPR Pusaka Dana & $0 \%$ & $0 \%$ & $2 \%$ & $2 \%$ \\
4. & BPR Ragam Peran mandiri & $0 \%$ & $0 \%$ & $0 \%$ & $3 \%$ \\
5. & BPR Tunas Jaya Global & $5 \%$ & $5 \%$ & $5 \%$ & $6 \%$ \\
6. & BPR Aneka Danaraya & $2 \%$ & $2 \%$ & $1 \%$ & $4 \%$ \\
7. & BPR Gita Makmur Utama & $4 \%$ & $4 \%$ & $5 \%$ & $8 \%$ \\
8. & BPR Sisibahari Dana & $1 \%$ & $3 \%$ & $2 \%$ & $10 \%$ \\
9. & BPR Matahari Artadaya & $1 \%$ & $1 \%$ & $2 \%$ & $7 \%$ \\
10. & BPR Tritama Lumbung Cemerlang d/h Ra & $2 \%$ & $2 \%$ & $2 \%$ & $2 \%$ \\
11. & BPR Bintang EkoNo.mi Sejahtera & $0 \%$ & $1 \%$ & $1 \%$ & $2 \%$ \\
12. & BPR Makmur Merata & & &
\end{tabular}


13. BPR Rizky Barokah

14. BPR Kuta Bumi Sidomukti

15. BPR Artha Makmur Lestari

16. BPR Fidusia Civitas

17. BPR Nusantara Bona Pasogit 12

18. BPR Arta Jakarta

19. BPR Vinski Mukti Arta

20. BPR Rifi Maligi

21. BPR Sehat Sejahtera

22. BPR Bumidhana Adigraha

23. BPR Artha Mitra Usaha

24. BPR Makmur Artha Sedaya

25. BPR Asri Cikupa Karya

26. BPR Muara Sumber Dana

27. BPR Surya Prima Persada

28. BPR Kerta Raharjau

\begin{tabular}{cccc}
$2 \%$ & $2 \%$ & $1 \%$ & $2 \%$ \\
$4 \%$ & $6 \%$ & $14 \%$ & $18 \%$ \\
$6 \%$ & $4 \%$ & $7 \%$ & $11 \%$ \\
$3 \%$ & $4 \%$ & $4 \%$ & $4 \%$ \\
$2 \%$ & $3 \%$ & $2 \%$ & $3 \%$ \\
$3 \%$ & $3 \%$ & $3 \%$ & $5 \%$ \\
$4 \%$ & $4 \%$ & $6 \%$ & $4 \%$ \\
$1 \%$ & $4 \%$ & $2 \%$ & $4 \%$ \\
$3 \%$ & $4 \%$ & $3 \%$ & $7 \%$ \\
$2 \%$ & $1 \%$ & $4 \%$ & $5 \%$ \\
$1 \%$ & $1 \%$ & $2 \%$ & $2 \%$ \\
$1 \%$ & $3 \%$ & $2 \%$ & $8 \%$ \\
$1 \%$ & $3 \%$ & $4 \%$ & $4 \%$ \\
$12 \%$ & $6 \%$ & $15 \%$ & $17 \%$ \\
$0 \%$ & $0 \%$ & $1 \%$ & $17 \%$ \\
$2 \%$ & $1 \%$ & $2 \%$ & $5 \%$ \\
$12 \%$ & $6 \%$ & $15 \%$ & $18 \%$ \\
$0 \%$ & $0 \%$ & $0 \%$ & $0 \%$ \\
$2 \%$ & $3 \%$ & $3 \%$ & $6 \%$ \\
\hline
\end{tabular}

Sumber: Data diolah, 2020

Nilai Minimum

Nilai Rata - Rata

Pada Tahun 2018, NPL paling tinggi pada BPR Muara Sumber Dana yaitu sebesar $15 \%$ sedangkan NPL yang paling rendah terjadi pada, BPR Pusaka Dana, dan BPR Tunas Jaya Global yaitu sebesar 0\%.

Dana Pihak Ketiga yang bersumber dari masyarakat yang bertujuan untuk mendukung kegiatan operasional dari BPR. Simpanan pihak ketiga ini terdiri dari tabungan dan deposito. Dana Pihak Ketiga BPR di kabupaten Tangerang dapat dilihat pada Tabel 5 .

Data pada Tabel 4 menunjukkan bahwa pada tahun 2016, DPK paling tinggi pada BPR Fidusia Civitas yaitu sebesar 99.24\% sedangkan DPK yang paling rendah terjadi pada BPR Ragam Peran mandiri, yaitu sebesar 22.80\%. Pada Tahun 2017, DPK paling tinggi pada BPR Artha Mitra Usaha dan BPR Fidusia Civitas sedangkan DPK yang paling rendah terjadi pada BPR Pusaka Dana. Pada Tahun 2018, DPK paling tinggi pada BPR Artha Mitra Usaha, dan BPR Muara Sumber Dana sedangkan DPK yang paling rendah terjadi pada BPR Sehat Sejahtera. Pada Tahun 2019, DPK paling tinggi pada BPR Artha Mitra Usaha sedangkan DPK yang paling rendah pada BPR Sehat Sejahtera.

Tabel 4

DPK BPR di Kabupaten Tangerang periode 2016 - 2019

\begin{tabular}{|c|c|cccc|}
\hline \multirow{2}{*}{ No. } & \multirow{2}{*}{ Bank } & \multicolumn{3}{|c|}{ Tahun } \\
\cline { 3 - 6 } & & 2016 & 2017 & 2018 & 2019 \\
\hline 1. & BPR Akasia Mas & $55.96 \%$ & $58.20 \%$ & $65.75 \%$ & $77.42 \%$ \\
2. & BPR Marcorindo Perdana & $50.37 \%$ & $52.83 \%$ & $52.87 \%$ & $57.90 \%$ \\
3. & BPR Pusaka Dana & $29.04 \%$ & $26.02 \%$ & $48.02 \%$ & $36.58 \%$ \\
4. & BPR Ragam Peran mandiri & $22.80 \%$ & $30.14 \%$ & $35.01 \%$ & $50.31 \%$ \\
5. & BPR Tunas Jaya Global & $60.39 \%$ & $55.88 \%$ & $62.14 \%$ & $66.61 \%$
\end{tabular}




\begin{tabular}{|c|c|c|c|c|c|}
\hline 6. & BPR Aneka Danaraya & $69.98 \%$ & $65.45 \%$ & $67.14 \%$ & $68.74 \%$ \\
\hline 7. & BPR Gita Makmur Utama & $70.35 \%$ & $66.48 \%$ & $57.59 \%$ & $56.85 \%$ \\
\hline 8. & BPR Sisibahari Dana & $63.02 \%$ & $70.66 \%$ & $79.42 \%$ & $90.55 \%$ \\
\hline 9. & BPR Matahari Artadaya & $52.39 \%$ & $41.34 \%$ & $53.34 \%$ & $63.19 \%$ \\
\hline 10. & BPR Tritama Lumbung Cemerlang d/h Ra & $53.10 \%$ & $51.41 \%$ & $44.92 \%$ & $47.04 \%$ \\
\hline 11. & BPR Bintang EkoNo.mi Sejahtera & $64.60 \%$ & $48.37 \%$ & $44.48 \%$ & $59.92 \%$ \\
\hline 12. & BPR Makmur Merata & $89.52 \%$ & $86.31 \%$ & $84.69 \%$ & $87.27 \%$ \\
\hline 13. & BPR Rizky Barokah & $88.49 \%$ & $80.05 \%$ & $79.57 \%$ & $75.67 \%$ \\
\hline 14. & BPR Kuta Bumi Sidomukti & $60.07 \%$ & $67.04 \%$ & $78.61 \%$ & $90.63 \%$ \\
\hline 15. & BPR Artha Makmur Lestari & $69.73 \%$ & $81.99 \%$ & $77.76 \%$ & $73.73 \%$ \\
\hline 16. & BPR Fidusia Civitas & $99.24 \%$ & $99.27 \%$ & $93.54 \%$ & $88.87 \%$ \\
\hline 17. & BPR Nusantara Bona Pasogit 12 & $65.98 \%$ & $83.75 \%$ & $64.50 \%$ & $59.80 \%$ \\
\hline 18. & BPR Arta Jakarta & $78.02 \%$ & $70.69 \%$ & $66.99 \%$ & $70.04 \%$ \\
\hline 19. & BPR Vinski Mukti Arta & $57.21 \%$ & $63.22 \%$ & $61.96 \%$ & $71.00 \%$ \\
\hline 20. & BPR Rifi Maligi & $43.56 \%$ & $44.75 \%$ & $44.55 \%$ & $45.83 \%$ \\
\hline 21. & BPR Sehat Sejahtera & $27.38 \%$ & $34.54 \%$ & $37.81 \%$ & $33.52 \%$ \\
\hline 22. & BPR Bumidhana Adigraha & $89.28 \%$ & $93.57 \%$ & $97.03 \%$ & $98.58 \%$ \\
\hline 23. & BPR Artha Mitra Usaha & $98.87 \%$ & $99.09 \%$ & $98.36 \%$ & $98.95 \%$ \\
\hline 24. & BPR Makmur Artha Sedaya & $92.75 \%$ & $71.73 \%$ & $45.22 \%$ & $47.13 \%$ \\
\hline 25. & BPR Asri Cikupa Karya & $70.75 \%$ & $58.22 \%$ & $66.42 \%$ & $80.00 \%$ \\
\hline 26. & BPR Muara Sumber Dana & $96.35 \%$ & $93.55 \%$ & $98.21 \%$ & $98.24 \%$ \\
\hline 27. & BPR Surya Prima Persada & $44.31 \%$ & $43.03 \%$ & $53.35 \%$ & $39.99 \%$ \\
\hline \multirow[t]{4}{*}{28.} & BPR Kerta Raharjau & $73.38 \%$ & $72.90 \%$ & $74.38 \%$ & $84.56 \%$ \\
\hline & Nilai Maksimum & $99.24 \%$ & $99.27 \%$ & $98.36 \%$ & $98.95 \%$ \\
\hline & Nilai Minimum & $22.80 \%$ & $26.02 \%$ & $35.01 \%$ & $33.52 \%$ \\
\hline & Nilai Rata - Rata & $65.60 \%$ & $64.66 \%$ & $65.49 \%$ & $68.53 \%$ \\
\hline
\end{tabular}

Penelitian ini menggunakan model analisis regresidalam pengujian hipotesis. Rangkuman hasil pengolahan data tersebut dapat dilihat pada Tabel 6. sebagai berikut :

Tabel 5

Rangkuman Hasil Analisis Regresi

\begin{tabular}{|c|c|c|c|c|c|}
\hline \multirow{2}{*}{$\begin{array}{l}\text { Variabel Terikat } \\
\text { ROA }\end{array}$} & \multicolumn{2}{|c|}{$\begin{array}{l}\text { Variabel Bebas Koefisien Regresi } \\
\text { Signifikansi }\end{array}$} & \multicolumn{3}{|c|}{ Std. Error t-hitung } \\
\hline & Intersep & -0.827 & 1.982 & -0.417 & 0.677 \\
\hline & LDR & 0.061 & 0.019 & 3.182 & 0.002 \\
\hline & NPL & -0.152 & 0.048 & -3.144 & 0.002 \\
\hline & DPK & 0.012 & 0.005 & 2.258 & 0.026 \\
\hline \multirow{2}{*}{\multicolumn{2}{|c|}{$\begin{array}{r}\text { R-Square } \\
\text { Adjusted R-Square }\end{array}$}} & 0.194 & \multicolumn{2}{|c|}{ F-hitung } & 8.482 \\
\hline & & 0.171 & \multicolumn{2}{|c|}{$\begin{array}{r}\text { Signikan } \\
\text { si }\end{array}$} & 0.000 \\
\hline
\end{tabular}


Melalui data pada Tabel 6dapat diperoleh model persamaan regresi linear berganda sebagai berikut :

$$
\mathrm{ROA}=-0.827+0.061 \mathrm{LDR}-0.152 \mathrm{NPL}+0.012 \mathrm{DPK}
$$

Koefisien $\alpha=-0.827$ merupakan nilai ROA sama dengan -0.827 ketika nilai variabel LDR, NPL dan DPK sama dengan nol (0).

$\mathrm{B}_{1}=0.061$ adalah nilai koefisien untuk variabel LDR. Nilai 0.061 menunjukkan bahwa untuk setiap kenaikan nilai variabel LDR sebanyak $1 \%$ akan menaikkan nilai ROA sebesar $0.061 \%$ dengan variabel lainnya diasumsikan bernilai konstan. $\mathrm{B}_{2}=-0.152$ adalah nilai koefisien untuk variabel NPL. Nilai -0.152 menunjukkan bahwa untuk setiap kenaikan nilai variabel NPL sebanyak $1 \%$ akan menurunkan nilai ROA sebesar $0.151 \%$ dengan variabel lainnya diasumsikan bernilai konstan. Koefisien yang bernilai negatif (-) memiliki arti bahwa NPL berpengaruh negatif terhadap Profitabilitas. $\mathrm{B}_{3}=0.012$ adalah nilai koefisien untuk variabel DPK. Nilai 0.014 menunjukkan bahwa untuk setiap kenaikan nilai variabel DPK sebanyak $1 \%$ akan menaikkan nilai ROA sebesar $0.014 \%$ dengan variabel lainnya diasumsikan bernilai konstan.

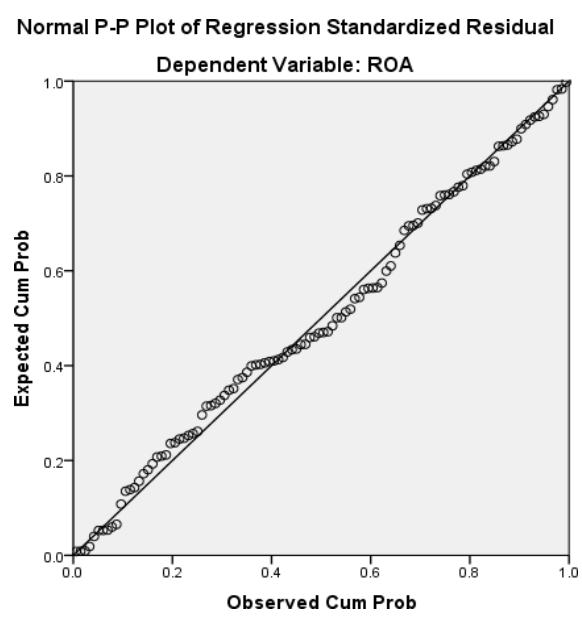

\section{Gambar 1.Plot Sisaan Regresi}

Adjusted $\mathrm{R}^{2}=0.171$ berarti variabel LDR, NPL, dan DPK mampu menjelaskan variasi Profitabilitas (ROA) sebanyak $17.1 \%$ dan sisanya $82.9 \%$ dijelaskan oleh faktor faktor pengaruh lain yang tidak ikut masuk di dalam model. Selanjutnya dilakukan uji asumsi klasik ini untuk mendeteksi apakah model regresi disusun tidak terjadi bias. Hasil uji normalitas, terlihat plot sisaan (residuals) mengikuti garis diagonal, sehingga dapat dikatakan sisaan menyebar dengan distribusi normal.

Hasil uji formal kenormalan dengan uji Kolmogorov-Smirnov. Diperoleh luaran (output) uji Kolmogorov-Smirnov dalam Tabel 7. Hipotesis nol $\left(\mathrm{H}_{0}\right)$ untuk uji Kolmogrov-Smirnov adalah sisaan menyebar dengan distribusi normal. Berdasarkan Tabel 7. Diperoleh bahwa nilai signifikansi $0.200>0.05$, sehingga keputusan adalah menerima hipotesis nol yang berarti bahwa sisaan dari model regresi yang telah diperoleh menyebar normal. 
Tabel 7.

Uji Kolmogorov-Smirnov

One-Sample Kolmogorov-Smirnov Test

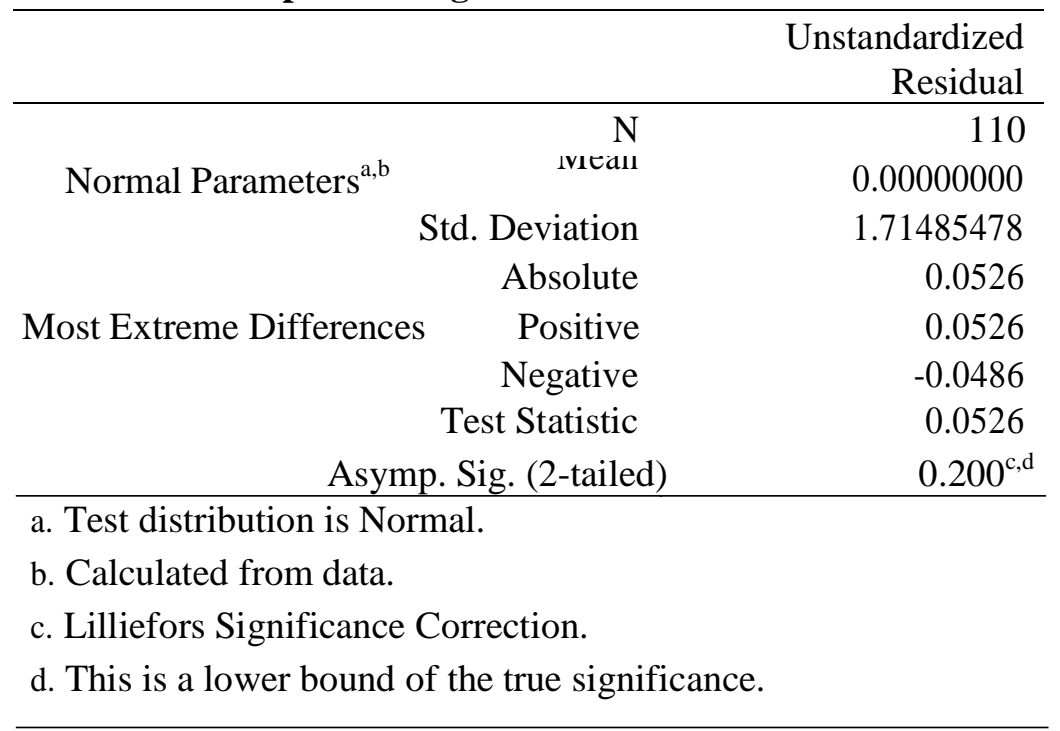

Untuk mengetahui keberadaan variabel - variabel yang saling berkorelasi kuat (multikolinearitas) pada model regresi dapat dilakukan dengan melihat nilai Variance Inflation Factor(VIF) dan nilai Tolerance dengan ketentuan VIF $<10$ dan Tolerance $>0.1$. Berdasarkan Tabel 8 Nilai VIF untuk setiap variabel bebas adalah lebih kecil dari 10 dengan Tolerance lebih besar dari 0.1 , hal ini berarti tidak terdapat multikolinearitas antar variabel dalam model regresi.

\section{Tabel 7}

Hasil Uji Multikolinieritas

Coefficients $^{\mathrm{a}}$

\begin{tabular}{|c|c|c|c|c|c|c|c|}
\hline \multirow[b]{3}{*}{ Model } & \multirow{2}{*}{\multicolumn{2}{|c|}{$\begin{array}{l}\text { Unstandardized } \\
\text { Coefficients }\end{array}$}} & \multirow{2}{*}{\multicolumn{3}{|c|}{$\begin{array}{l}\text { Standardized } \\
\text { Coefficient }\end{array}$}} & \multicolumn{2}{|l|}{$\begin{array}{l}\text { Collinearity } \\
\text { Statistic }\end{array}$} \\
\hline & & & & & & Statistic & \\
\hline & B & Std. Error & Beta & $\mathrm{T}$ & Sig. & Tolerance & VIF \\
\hline 1 (Constant) & -0.827 & 1.982 & & $\begin{array}{c}- \\
0.417\end{array}$ & $\begin{array}{c}0.67 \\
7\end{array}$ & & \\
\hline LDR & 0.061 & 0.019 & 0.322 & 3.182 & $\begin{array}{c}0.00 \\
2\end{array}$ & 0.743 & $\begin{array}{c}1.34 \\
6\end{array}$ \\
\hline NPL & -0.152 & 0.048 & -0.288 & $\begin{array}{c}- \\
3.144\end{array}$ & $\begin{array}{c}0.00 \\
2\end{array}$ & 0.905 & $\begin{array}{c}1.10 \\
5\end{array}$ \\
\hline DPK & 0.012 & 0.005 & 0.129 & 2.258 & $\begin{array}{c}0.02 \\
6\end{array}$ & 0.746 & $\begin{array}{c}1.34 \\
0\end{array}$ \\
\hline
\end{tabular}

Sumber: Data diolah, 2020

Uji autokorelasi yang digunakan dalam penelitian ini adalah dengan nilai statistik Durbin-Watson dengan membandingkan nilai tabel dengan nilai hitung Durbin-Watson. Berdasarkan Tabel 9.diketahui bahwa nilai hitung Durbin-Watson adalah 2. dan berdasarkan Lampiran 4. Untuk $\mathrm{n}=111$ dan $\mathrm{k}=4$ diperoleh nilai $\mathrm{dL}=1.6355 \mathrm{dan} \mathrm{dU}=$ 1.7463. Oleh karena $\mathrm{dU}=1.7463<1.914<4-\mathrm{dU}=2.3645$ maka disimpulkan bahwa tidak terjadi autokorelasi dalam model regresi. 
Tabel 8

Hasil Uji Autokorelasi

Model Summary ${ }^{\text {b }}$

\begin{tabular}{lrrrrrr}
\hline Model & R & R Square & $\begin{array}{r}\text { Adjusted R } \\
\text { Square }\end{array}$ & $\begin{array}{l}\text { Std. Error of the } \\
\text { Estimate }\end{array}$ & Durbin-Watson \\
\hline 1 & $0.440^{\mathrm{a}}$ & 0.194 & 0.171 & & 1.739 & 1.914 \\
\hline
\end{tabular}

a. Predictors: (Constant), DPK, NPL, LDR

b. Dependent Variable: ROA

Untuk menguji gejala heteroskedastisitas digunakan Uji Glejser. Tabel 10 Merupakan hasil tabel hasil uji Glejser, karena nilai signifikansi t setiap variabel lebih dari taraf nyata $\alpha=0.05$ maka tidak cukup bukti untuk menolak hipotesis nol yang berarti bawa tidak ada variabel bebas yang signifikan berpengaruh terhadap nilai mutlak dari sisaan (residuals), dengan demikian disimpulkan bahwa tidak terjadi heteroskedastisitas pada model regresi.

Tabel 10.

Hasil Uji Glejser

Coefficients $^{\mathrm{a}}$

\begin{tabular}{|c|c|c|c|c|c|c|c|c|}
\hline \multirow{2}{*}{\multicolumn{2}{|c|}{ Model }} & \multicolumn{2}{|c|}{$\begin{array}{l}\text { Unstandardized } \\
\text { Coefficients. }\end{array}$} & \multicolumn{2}{|c|}{$\begin{array}{l}\text { Standardized } \\
\text { Coefficients }\end{array}$} & \multirow[b]{2}{*}{ Sig. } & \multicolumn{2}{|c|}{$\begin{array}{l}\text { Collinearity } \\
\text { Statistics }\end{array}$} \\
\hline & & B & Std. Error & Beta & $\mathrm{t}$ & & $\begin{array}{c}\text { Toleranc } \\
\mathrm{e}\end{array}$ & VIF \\
\hline \multirow[t]{6}{*}{1} & (Constant) & - & 1.207 & & - & 0.57 & & \\
\hline & & 0.683 & & & 0.566 & 2 & & \\
\hline & LDR & 0.013 & 0.012 & 0.125 & 1.142 & $\begin{array}{c}0.25 \\
6\end{array}$ & 0.743 & 1.346 \\
\hline & NPL & - & 0.029 & -0.093 & - & 0.34 & 0.905 & 1.105 \\
\hline & & 0.028 & & & 0.942 & 9 & & \\
\hline & DPK & 0.015 & 0.009 & 0.282 & 1.623 & $\begin{array}{c}0.10 \\
7\end{array}$ & 0.746 & 1.340 \\
\hline
\end{tabular}

Uji parsial memiliki tujuan untuk mengetahui apakah variabel $L D R, N P L$, dan DPK berpengaruh terhadap Profitabilitas $(R O A)$ secara parsial atau terpisah. Pada Tabel 11. disajikan hasil perhitungan t-hitung dan nilai signifikansi t.

\section{Tabel 11}

Tabel Uji t

\begin{tabular}{lrrcr} 
Variabel & t-hitung & t-tabel & Sig & Keterangan \\
\hline LDR & 3.182 & 1.659 & 0.00 & Signifikan \\
& & & 2 & \\
NPL & -3.144 & 1.659 & 0.00 & Signifikan \\
& & & 2 & \\
DPK & 2.258 & 1.659 & 0.02 & Signifikan \\
\multicolumn{5}{c}{6} \\
\hline \multicolumn{5}{c}{ Sumber: Data diolah, 2020}
\end{tabular}


Data Tabel 11, dapat dilihat bahwa variabel LDR memiliki nilai t hitung yang lebih besar dari t tabel $(3,182>1,659)$ dengan nilai signifikansi 0.002 yang lebih kecil dari 0.05 . Hasil ini menunjukkan bahwa risiko likuiditas yang diwakili oleh LDR berpengaruh positif dan signifikan terhadap profitabilitas yang diwakili oleh ROA. Variabel NPL memiliki nilai $\mathrm{t}$ hitung yang lebih kecil dari t tabel $(-3,144<1,659)$ dengan nilai signifikansi 0,002 yang lebih kecil dari 0,05. Hasil ini menunjukkan bahwa risiko kredit yang diwakili oleh NPL berpengaruh negatif dan signifikan terhadap profitabilitas yang diwakili oleh ROA. Variabel DPK memiliki nilai $\mathrm{t}$ hitung yang lebih besar dari t tabel $(2,258>1,659)$ dengan nilai signifikansi 0,026 yang lebih kecil dari 0.05 . Hasil ini menunjukkan bahwa Dana Pihak Ketiga diwakili oleh DPK berpengaruh positif dan signifikan terhadap profitabilitas yang diwakili oleh ROA.

Hasil uji kelayakan model (uji F) dalam penelitian ini dapat dilihat pada Tabel 12. Data pada Tabel 12 menunjukkan nilai sigifikansi $F$ adalah sebesar 0,000 yang lebih kecil dari $0,05(\mathrm{~F}<$ Sig) yang berarti variabel independen berpengaruh signifikan secara serempak atau bersama-sama terhadap variabel dependen, sehingga model penelitian dinyatakan layak digunakan sebagai model regresi.

Tabel 12.

Hasil Uji F ANOVA ${ }^{a}$

\begin{tabular}{llrrrrr}
\hline & & $\begin{array}{r}\text { Sum of } \\
\text { Squares }\end{array}$ & df & $\begin{array}{r}\text { Mean } \\
\text { Square }\end{array}$ & F & Sig. \\
\hline 1 & Regression & 76.952 & 3 & 25.651 & 8.482 & $0.000^{\mathrm{b}}$ \\
& Residual & 320.539 & 106 & 3.024 & & \\
& Total & 397.491 & 109 & & & \\
\hline
\end{tabular}

Sumber: Data diolah, 2020

Koefisien determinasi merupakan alat utama untuk mengukur ketepatan garis regresi terhadap sebaran datanya. Koefisien determinasi dalam penelitian ini disajikan dalam Tabel 13. Sebagai berikut

Tabel 13.

Koefisien Determinasi

\begin{tabular}{cccccc}
\hline Model & R & R square & $\begin{array}{c}\text { Adjusted R } \\
\text { Square }\end{array}$ & $\begin{array}{c}\text { Std Error of } \\
\text { the estimate }\end{array}$ & $\begin{array}{c}\text { Durbin- } \\
\text { Watson }\end{array}$ \\
\hline 1 & $0,440^{\mathrm{s}}$ & 0,194 & 1,171 & 1,739 & 1,914 \\
\hline
\end{tabular}

Sumber: Data diolah, 2020

Besarnya nilai adjusted $\mathrm{R}$ square adalah sebesar 0,171 yang artinya sebesar $17,1 \%$ variasi profitabilitas dipengaruhi oleh risiko likuiditas, risiko kredit, dan Dana Pihak Ketiga, sedangkan sebesar $82,9 \%$ dipengaruhi oleh faktor-faktor lain yang tidak dimasukkan ke dalam model penelitian.

\section{Simpulan dan Saran}

Bersumber pada pengujian hipotesis yang sudah dicoba hingga bisa disimpulkan sebagian perihal sebagai berikut: Likuiditas mempengaruhi positif serta signifikan terhadap profitabilitas pada BPR di Kabupaten Tangerang periode 2016- 2019. Nilai tersebut menampilkan bila nilai likuiditas bertambah, hingga profitabilitas yang dicapai 
oleh BPR Tangerang pula bertambah. Resiko Kredit mempengaruhi negatif serta signifikan terhadap profitabilitas pada BPR di Kabupaten Tangerang periode 2016- 2019. Hasil tersebut menampilkan bila resiko kredit yang dialami bertambah, hingga profitabilitas yang dicapai oleh BPR Tangerang hendak menyusut, serta kebalikannya. Dana Pihak Ketiga mempengaruhi positif serta signifikan terhadap profitabilitas pada BPR di kabupaten Tangerang periode 2016- 2019.

BPR Tangerang dianjurkan mencermati Likuidititas (LDR), Risiko Kredit (NPL) dan Dana Pihak Ketiga. Keahlian BPR Tangerang dalam mengelola Risiko Kredit yang diharapkan agar dapat dipertahankan atau lebih ditingkatkan. Dari aspek likuiditas, dianjurkan kepada BPR Tangerang untuk lebih mengoptimalkan lagi penyaluran kreditnya namun tetap melindungi agar tingkat LDR tetap berada dalam batas aman Bank Indonesia. Peneliti hanya terbatas meneliti variabel likuiditas (LDR), risiko kredit (NPL) dan dana pihak ketiga dan Profitabilitas (ROA). Disarankan kepada peneliti selanjutnya untuk dapat menambahkan variabel-variabel lain yang tidak dicantumkan didalam penelitian ini seperti variabel Loan to Asset Ratio, Net Interest Margin, Efisiensi Operasional dan kualitas Aktiva produktif serta diharapkan penelitian selanjutnya menambah referensi terhadap variabel-variabel yang diteliti serta rentang waktu.

\section{Daftar Pustaka}

Abdul Sattar. 2014. Impact of Interest Rate Changes on the Profitability of four Major Commercial Banks in Pakistan. International Journal of Business and Economic, 4 (1): 142-154.

Ali Sulieman Alshatti 2015. The Effect of the Liquidity Management on Profitabilityin the Jordanian Commercial Banks. International Journal of Business and Economic, 10 (1): 62-71.

Erlangga H, WO Sifatu, D Wibisono, AO Siagian, R Salam, M Mas'adi, 2020 Pharmaceutical Business Competition in Indonesia: A Review Systematic Reviews in Pharmacy 11 (10), 617-623

Evans Ovamba Kiganda. 2014. Effect of Macroeconomic Factors on Commercial Banks Profitability in Kenya: Case of Equity Bank Limited. International Journal of Business and Economic, 5 (2): 46-56.

Fahrizal. 2014 Pengaruh Risiko Usaha Terhadap Profitabilitas Pada Lembaga Perkreditan Desa di Kecamatan Kuta Kabupaten Badung Periode 2010- 2012. E-Jurnal Manajemen Universitas Udayana, 3(10): 3067-3077

Kasmir. 2014. Bank dan Lembaga Keuangan Lainnya. Jakarta: PT Raja Grafindo Persada

Mahardika, I M.A., Cipta, W., dan Yudiaatmaja, F. 2014. Pengaruh Kredit Bermasalah dan Penyaluran Kredit Terhadap Laba Pada Lembaga Perkreditan Desa (LPD). eJournal Bisma Universitas Pendidikan Ganesha Jurusan Manajemen, 2 (1): 110.

Maheswari, Kadek Indah. 2014. Pengaruh NPL terhadap ROA dengan Mediasi CAR dan BOPO pada Perbankan Indonesia. E-Jurnal Manajemen Universitas Udayana, 3(4): 1119-1139. 
Malik, Muhammad Faizan, et al., 2014. Interest Rate and Its Effect on Bank`s Profitability. Journal of Applied Environmental and Biological Sciences, 4(8): 225-229. .

Million Gizaw, 2015. The Impact Of Credit Risk On Profitability Performance Of Commercial Banks In Ethiopia. International Journal of Business and Economic, 9 (2): 59-66.

Muhammad Fahrul Rozi Syaf'I dan Ellen Rusliati. 2016. Credit Risk, Market Risk, Operational Risk and Liquidity Risk on Proftability of Banks in Indonesia. International Journal of Business and Economic, 15 (2): 78-88.

Nuray, Islatince. 2015. Analysis Of The Factors That Determine The Profitability Of The Deposit Banks In Turkey. International Journal of Applied Finance and Banking, 5 (3): 175-186.

Riesmiyantiningtias N, Siagian AO, 2020, 'Analisis Laporan Keuangan Untuk Menilai Kinerja Keuangan Perusahaan Pada PT. Midi Utama Iindonesia TBK', Jurnal Akrab Juara, 5 (4), 244-254

Olanye, Festus Oladipupo. 2015. Determinants Of Deposit Money Banks` Profitability In Nigeria. International Journal of Business and Management, 4 (9): 11-18.

Pamularsih, Diyah. 2015. Pengaruh LDR, NPL, NIM, BOPO, CAR dan Suku Bunga Terhadap Profitabilitas pada Sektor Perbankan yang Terdaftar di Bursa Efek Indonesia Periode Tahun 2009-2013. Jurnal Ilmiah Mahasiswa S1 Akuntansi Universitas Pandanaran, 1 (1).

Prasetyo, Dwi Agung dan Darmayanti, Ni Putu Ayu. 2015. Pengaruh Risiko Kredit, Likuiditas, Kecukupan Modal, dan Efisiensi Operasional Terhadap Profitabilitas pada PT BPD Bali. E-Jurnal Manajemen Unud, 4 (9): 2590 - 2617.

Rahmi, Ceria Lisa. 2014. Pengaruh Risiko kredit, Risiko Likuiditas, dan Risiko Tingkat Bunga Terhadap Profitabilitas (Studi Empiris pada perusahaan Perbankan Terdaftar di Bursa Efek Indonesia). Skripsi. Fakultas Ekonomi Universitas Negeri Bandung

Rizwan Ali Khan \& Mutahhar Ali.. 2016. Impact of Liquidity on Profitability of Commercial Banks in Pakistan: An Analysis on Banking Sector in Pakistan. International Journal of Business and Economic, 16 (1): 53-59.

Saleh R, AO Siagian 2020. Sponsorship dalam Menciptakan Sikap Merek Jurnal Bisnis Terapan 4 (1), 13-22. DOI: https://doi.org/10.24123/jbt.v4i1.2404.

Siagian, AO, N Indra, 2019, "Pengetahuan Akuntansi Pelaku Usaha Mikro Kecil dan Menengah (UMKM) Terhadap Laporan Keuangan”, Syntax Literate; Jurnal Ilmiah Indonesia, 4(12), 17-35 vol: 4. DOI: http://dx.doi.org/10.36418/syntax-literate.v4i12.825

Siagian, AO, 2019, "Pengaruh Daya Tarik Iklan Dan Penempatan Produk Terhadap Kesadaran Merek Grab di Acara Indonesian Idol 2018”, Jurnal Pemasaran Kompetitif, 2(1), 118-130. DOI: http://dx.doi.org/10.32493/jpkpk.v3i1.3621 
Siagian, AO, 2020, "Pengaruh Dana Pihak Ketiga, Modal Bank, Jumlah Kantor Cabang, Tingkat Suku Bunga dan Jumlah Uang Beredar Terhadap Jumlah Kredit UMKM Bank BUMN", Syntax Literate; Jurnal Ilmiah Indonesia, 5 (5), 1-17. DOI: http://dx.doi.org/10.36418/syntaxliterate.v5i5.1140

Siagian, AO, 2020, "Contribution of Inventory Accounting Systems in Improving Inventory Internal Control".Journal of Sosial Science, 1(2), 1-6. http://jsss.co.id/index.php/jsss/article/view/12

Siagian, AO, 2020, "Keterkaitan Individualitas Manajerial Pemasaran Dalam Menghadapi Revolusi Industri 4.0 Terutama Pada Perusahaan Manufaktur Di Jawa Tengah", Syntax Literate; Jurnal Ilmiah Indonesia 5 (10), 980-994. DOI: http://dx.doi.org/10.36418/syntax-literate.v5i10.1669

Siagian AO, Gunartin, K Nufus, HS Nur'aini Yusuf, A Maddinsyah, A Muchtar, 2020. A Systematic Literature Review of Education Financing Model in Indonesian School.

Sukmawati, Ni Made Elin dan Purbawangsa, Ida Bagus Anom. 2016. Pengaruh Pertumbuhan Dana Pihak Ketiga, Pertumbuhan Risiko Kredit, Likuiditas, dan Kondisi Ekonomi Terhadap Profitabilitas, E-Jurnal Manajemen Unud, 5 (9): 5398-5432 
